\title{
The Depiction of Native American in the Novels of Forrest Carter
}

\author{
Suryo Sudiro, M. Hum \\ University of Technology Yogyakarta, Indonesia
}

Doi: 10.19044/llc.v7no1a2

URL:http://dx.doi.org/10.19044/1lc.v7no1a2

\begin{abstract}
Novelists use attractive and meaningful words to make readers pay attention to their novels. These words are likely chosen from the developing issues at the time of writing. This article studies how literary studies can show it to public. The focus is on interpreting why an author writes about a clan in a specific case. Indians, the native people of America, become necessary in Forrest Carter's novels The Outlaw Josey Wales, The Education of Little Tree, and Watch for me on the Mountain. Forrest Carter shows how Native American interact with white men. He implicitly emphasizes his interest in presenting Native American. To explore and interpret the depiction of Native American in the three novels, this article uses the theory of historicism. With historicism, this article shows an interpretation that is based on the events found in history books and articles. In addition, this article shows the life of Forrest Carter especially his political life. Based on this analysis of the author's writing, the relevant historical events and the author's life, this article clarifies why Native American are important in Forrest Carter's novels and why he chooses the Cherokee and Apache tribes. This article finds that Forrest Carter's writings are propaganda. The writings become political persuasion to persuade people.
\end{abstract}

Keywords: Apache, Cherokee, Historicism, Interpretation, Political Persuasion.

\section{Introduction}

A novel, apart from being a literary work, records important events that happen in a specific time period and place and therefore becomes a documentation of a people's lives. A novel also shows that the author has a special interest in writing about events considered historically relevant and memorable. These historical events when linked to the author may reveal political interests. Viewed in another way, the use of a literary genre such as the novel, is justifiably used to learn about human history. Fact and fiction, as 
shown by Richard Ned Lebow (2009), are logically linked as they are interrelated. He states that facts relate to history and its understanding. For Lebow, history is also understood with the assistance of fiction since fiction relates individual human awareness to a wider understanding of historical events. Fiction enables readers to acquire a greater comprehension of history. Lebow (2009) in his article, Counterfactuals, History and Fiction" writes that:

"Twentieth century writers, whether or not they engage history, are heirs to this tradition. Many of their readers have come to accept fiction as a vehicle for stretching and challenging their consciousness and understanding of the world in ways history does not"

Fiction thus has a potential to broaden and challenge the human awareness and understanding of the world something that history is less able to do. Frank Ankersmit (2012) in his book Meaning, Truth, and Reference in Historical Representation, considers the significance of representational truth in fiction. He examines how a novel represents the truth of a past time. He writes that

"I now propose to discuss how historical writing may deepen our insight into the novel and, more specifically, whether our investigations into the nature of representational truth will permit us to speak of the truth of the novel." (Ankersmit, 2012: 118-119).

To him, history has a potential to support the effort of an author to represent historical facts in his novel. With an understanding of history, an author will write an accurate presentation in his writing.

The relations of newcomers and Native American in America form a part of American History. The story is rich in details that are exciting and sad. In fact, the history of newcomers and Native American has been written by newcomers who have interacted with Native American. As a consequence, history then is from the viewpoint and interests of the newcomers.

Donald L. Fixico (2009), in posing the question of what Native American history is, highlights the issue of point of view and writes "Without going into great detail, Indian history is perceived differently by Indians close to their traditions as opposed to academic historians. "Fixico reminds us that how Native American history is written depends on the position of the author relative to the subject. It is the writers who have the power to influence Native American history. This also happens when the history is written in a literary work such as a novel. What is told in the novel will be influenced by the interests of the author.

This article is a reading report of three novels written by Forrest Carter. The first novel is Watch for Me on the Mountain. It is a novel about Geronimo in the vision of Forrest Carter where Carter presents a different story of Geronimo and his people, the Apache people. 
The two other novels are The Outlaw Josey Wales and The Education of Little Tree. Both novels reflect the views of Carter. The reading then gives rise to two questions:

1. What are the important historical facts and information about Native American that can be taken from the novels?

2. What can be learned from Forrest Carter's representation of the Cherokee and Apache people in his three novels?

To help interpret the story in the novels, this article uses the theory of historicism. Historicism uses a method of analysing the historical context of a literary works to add rigor to the interpretation of the text. To this end, it includes developments in U.S. History related to the novel as well as the life history of Forrest Carter. The intent of this analysis is to make a contribution to the understanding of these three novels.

\section{Historicism}

An important part of reading is to accurately and rigorously interpret a text. To this end, the analysis is based on the theory of historicism. It is a critical way of using historical contexts to interpret texts. Paul Hamilton (2003: 2) states "Historicism (or 'historism' in this translation of Currius' Historismus) is a critical movement insisting on the prime importance of historical context to the interpretation of texts of all kinds" Historicism can be seen as an analytical instrument that brings together literary interpretation and historical explanation. It means drawing upon the events recorded in academic history books and comparing it to the story in the novels.

Historicism has also been chosen because of its potential to reveal some important matters about life found in a literary work. It makes it possible to see matters in the context of the space and time of the events. It can be used to view the historical period and the place of historical events. Historicism is a framework for understanding that a literary text relates to politics, religion, economics and other social conditions in a certain place and time, and that a discussion of a literary text is incomplete if it does not address the the world view presented in a literary text.

A consideration of the historical context leads to a comprehension of the social reality at the place and in the time written in the literary work. Historicism enables an analysis outside its fictional world. Rob Pope emphasises the historical dimension of the text that needs to be considered to counter the potential deceptiveness of an exclusively text-based analysis and writes that:

"There is a further complication, however. We must also recognize that texts exist in time and space. Every one of these products and processes is therefore constituted in a a variety of historical moments. The grand abstraction "the text" is always potentially deceptive." (Pope, 2002: 77). 
Ernst Troeltsch is the first thinker who introduces historicism to public and writes that historicism is "the fundamental historicization of all our thinking about man, his culture and his values" (Troeltsch in Beiser, 2011: 11). It is an essential view to see the humans' thought, culture and values. Beiser (2011) using Troeltsch's definition then asks how human's thought is historicized. For Beiser to historicize human thought is "to recognize that everything in the human world-culture, values, institutions, practices, rationality - is made by history, so that nothing has an eternal form, permanent essence or constant identity which transcends historical change." (2011: 11). It is to understand that all elements of human beings are the products of history. They do not have a static nature but a dynamic one, synchronous with history that changes time to time.

History is a significant factor in shaping how human beings think. It influences humans' consciousness. In other words, Beiser is making an argument that there is nothing to tell about humans without history. His view of history is found in historicism. He writes that "historicism grew out of the attempt to create a science of the human world, one on par with the sciences of the natural world" (2011: 12). He underlines that the social sciences are as important as natural sciences and historicism brings together the effort to understand human beings.

Philosophically, historicism is based on the events that are written in history. It considers the historical causes that make human beings what they are. However, it does not read the history only, but it also uses a second order understanding to reflect upon the events. Beiser writes

.... it should be plain that the historicists' concern was not first but second order history, i.e., historiography, the methods and standards of writing history. Hence historicism was an essentially philosophical tradition. It came into being in the late eighteenth century when historians began to reflect philosophically, or when philosophers began to reflect about history (2011: 17)

To him, historicism is a philosophic tradition. It does not tell what is in history but also, how and why a specific event happens.

\section{Cherokee and Apache Tribes in U.S. History}

This article draws upon existence of Native American in U.S. History that is close to the story of Forrest Carter in The Outlaw of Josey Wales, The Education of Little Tree and Watch for me on the Mountain. From the three novels there is some important information that may be checked in the history books about the U.S.

In The Outlaw of Josey Wales and The Education of Little Tree, Carter writes many stories about Cherokee people. He writes how they make contact with white men. Even, in The Education of Little Tree, Carter becomes the 
boy, the main character of the novel. The boy in the novel is a half Cherokee and lives with his Cherokee grandparents in the mountains.

In Watch for me on the Mountain, Carter starts his story from the how the bluecoat soldiers, a military power of northern U.S Government, arrest Geronimo, an Apache warrior. The bluecoat soldiers make Geronimo know that the white newcomers do not like him and his people, the Apache. They are not allowed to live in the same place as the white newcomers.

In Corbett's et. al. (2016) book on U.S. history, we can find that conflicts occur in the interactions between Native American and European newcomers. It happens when the newcomers claimed more land for themselves. However, it highlights the different principles of landownership between the Apache people and the newcomers and the behavior of the newcomer in the land they occupy. Corbet et. al. write "Clashing beliefs about landownership and use of the environment would be the greates area of conflict with Europeans" (2016: 17).

Corbett et. al. write how the European newcomers and Native American fight for the land occupied by the newcomers. They write

"European ideas about owning land as private property clashed with natives' understanding of land use. Native peoples did not believe in private ownership of land; instead, they viewed land as a resource to be held in common for the benefit of the group" (2016: 88).

The conflict is again on the understanding of what landership is. The newcomers occupy the land for personal ownership, but the Native American do not share this principle. They consider land a mutual property that is explored and exploited for mutual needs.

Forrest, in Watch for Me on the Mountain, also writes that some Native American women are raped by white soldiers and the Native American children are slaughtered but Corbett et. al. do not write it. They instead write:

"English settlers exacerbated tensions with local Indian tribes, especially the Yamasee, by expanding their rice and tobacco fields into Indian lands. Worse still, English traders took native women captive as payment for debts". (2016: 98)

and

"in the 1603s, half the Huron and Iroquois around The Great Lakes died of smallpox. As often the case with disease, the very young and the very old were the most vulnerable and had the highest mortality rates." (2016: 88).

The decreasing number of Native American is also caused by abortions. Corbet et. al write that

"One notable example was the use of the peacock flower to induce abortions: Indian and enslaved African women living in oppressive colonial regimes are said to have used this herb to prevent the birth of children into slavery." (2016: 90). 
Native American women do not want their children to be enslaved. They make their children die before delivered. This phenomenon surely has an impact on the growth of Native American population.

However, according to Corbet et. al., the white newcomers, do not sell and use Native American as slaves rather England newcomers enslaved Africans. They write that

"The English crown chartered the Royal African Company a monopoly over the transport of African Slaves to the English Colonies. Over the next four decades, the company transported around 350.000 Africans from their homelands." (2016: 88)

In The Outlaw Josey Wales, Forrest Carter writes that Josey Wales, the main character of the novel, has a smart Cherokee partner, Lone Watie. They work together to fight against the soldiers of the Union Army and people who sell them to the government. Carter writes how Josey respects Lone Watie. It illustrates how Carter seeks to show that he and people from his race respect Native American.

While, in The Education of Little Tree, Carter writes about his life, as a boy with his Cherokee grandparents. They look after him and taught him how to live in the mountains as a Cherokee. Again, Carter wants to make people know that Cherokee people have given valuable things to him. It seems Carter likes to tell that he is different from many people who considers Cherokee people or Native American are dangerous and harms their lives.

Watch for me on the Mountain is a novel that tells about the Geronimo and Apache people. Before reading more the novel, it is necessary to check the U.S. History. Boyer et. al. (2008: 2) write that the Apache tribe is one of the first inhabitants of America. They have lived in America since 7000 B.C. along with the Navajo, Inuit, Aleut and Eskimo people.

Johnson (1997: 408) writes that Geronimo is an Apache figure who waged war on US government soldiers. He was subsequently defeated by General Leonard Wood, the general of First U.S. Cavalry.

The Apache people in the 1600s clashed with Spanish colonizers and Catholic missions. They raided and stole Spanish horses. Then in the 1700s, Apache people either fled to Mexico or made peace with the Spanish to gain support against raids by Utes and Comanches (Boyer. 2008: 82). They occupied southern places in theU.S. and involved in wars not only with the white newcomers but also with other Native American.

They also fought in wars with Mexicans in the AmericantMexican War in the 1800s. They become stronger in the war because of their experiences. Their name is also mentioned as one of the Indian tribes that faced the U.S. army in the Civil War period. The U.S. soldiers brutally attacked the Indians in 1864. They even killed Indians who were not involved in war including their women and children (Boyer, 2008: 383). 
Indians kept fighting. They fought for their existence and land. After the U.S. Civil War, the U.S. Government attacked the Indians politically and sent its army to slaughter and depopulate areas occupied by the Indians. In 1886, the Apache leader, Geronimo surrendered (Boyer.2008: 384).

\section{The Life of Forrest Carter}

In order to make a logical interpretation of Forrest Carter's portrayal of Indians in his work it is also necessary to consider his life story,in particular his social and political life. This information supports the interpretation of his intention in writing the story in such a way.

A study of Carter's life will lead to an understanding of his political interests and why he chooses to highlight and even exaggerate certain events. The interpretation will not be just a claim but a logical statement.

Lowndes (2002) writes about Carter's political views and activities which opposed Black Rights in his home state. His given names are Asa Earl Carter. He is a politician in Alabama in 1954. He is a segregationist. He admires the Confederate Generals in the U.S. Civil War. He founds a racist organization, The Original Ku Klux Klan which attacked a black civil rights activist. Lowndes writes

"Asa ("Ace") Earl Carter embarked on his political life in Birmingham, Alabama in 1954 in the midst of the upheaval over civil rights. Beginning as a far-right radio commentator, he went on to become the leader of the statewide White Citizens' Council and public speaker for the white supremacist American States' Rights Association. He also edited a segregationist periodical called The Southerner that presented heroic depictions of Confederate generals, ranted against the threat of integration in everything from education to rock and roll, and warned of Communist conspiracies in both the Republican and Democratic Parties. The Council and the journal also functioned as a front for an underground vigilante group Carter founded called The Original Ku Klux Klan of the Confederacy. This cadre was known for extreme brutality, including the onstage assault of Nat "King" Cole during a Birmingham concert for an all-white audience, the beating of civil rights leader Fred Shuttlesworth and the stabbing of his wife, and for the castration of a randomly chosen, slightly retarded black man as a warning to civil rights activists".

From Lowndes (2002) we may conclude from Forrest Carter social and political life that he lived in an environment of people who defended the supremacy of white southerners. He also had a political ideology aspiring to a society with whites as the highest class of humans. He fought for it and against people who opposed his ideology.

The question is then where do Native American fit in Forrest Carter's racist ideology. In his novels, The Outlaw Josey Wales and The Education of 
Little Tree, he tells about how white people work together with a particular Native American tribe, the Cherokee. In The Education of Little Tree. Carter tells that he is a half-Cherokee boy who lives with his Cherokee grandparents. In many parts of the both novels, he depicts the good things about the Native American.

\section{Native American to Forrest Carter}

In Watch for Me on the Mountain, Forrest Carter starts his story with how Naiche, a character in the novel deals with Geronimo. Naiche knows how Geronimo fights against white superiority represented by white soldiers or in the novel called bluecoats. The white soldiers run after Geronimo since he refuses to surrender. Geronimo and some Apache people go to the south to find a place where they can live.

The bluecoats still try to find Geronimo and the Apache troops. They use scouts and some of whom are Apache. They use the scouts because they know the mountains more than they do. The Apache fight. They use their way of struggle to survive. They kill some scouts although they then die while protecting Geronimo and the women and children.

Forrest's depiction of the journey of the Apache has a parallel in the Trail of Tears concerning the journey of the Cherokee people in The Education of Little Tree. Carter describes how the U.S. Government chases Cherokee people away from their land. Cherokee people go but they do not use the transportation offered by the U.S. Government. They walk. On the trail, many Cherokee people die. They are mostly women and children.

Carter writes a different relation of a white and a Cherokee in his The Outlaw Josey Wales. In this novel Carter tells how Josey Wales, the main character in this novel, deals with a Cherokee. He works together with the Cherokee to run away from the Federal Union Army. He admires the Cherokee's fighting skills. The Cherokee helps him a lot to escape to Texas.

Then, in Watch for Me on the Mountain, Carter presents a particular version of Geronimo, a hero of Apache, to his readers. He uses his point of view to tell of the heroic struggle of Geronimo and his people to fight against the U.S. Government soldiers.

Apache people are not happy when the star chief of the bluecoat soldiers says, "You cannot become citizens of The United States. You cannot own property" (1978: 4). When the Apache asks, "why?". The star chief replies "Indians are not people. It is the law." (1978: 4). It makes the Apache angry. They only want to live in their land, but in the novel Carter writes, "There is no place for Apache. There is a place for all others. But there is no place for the Apache". (1978: 4). Even the Apache people ask rhetorically "Has God forsaken the Apache?" (1978: 5). 
The Apache people in Forrest Carter's writing are subordinated by the whites, represented by the U.S. Government military. The Apache people lose their land and they are forced to move away. They fight, and run, but the soldiers chase them. They are killed and their numbers decrease. Geronimo leads some Apache to move to Sierra Madre.

In Watch for Me on the Mountain, Carter chooses the Apache tribe to write about. In his two other novels, The Outlaw Josey Wales and The Education Little Tree, Carter writes about the Cherokee tribe. He writes that he is half Cherokee in The Education Little Tree. He admires the wisdom and intelligence of the Cherokee in The Outlaw Josey Wales. Even, in the beginning of his novels, it is written that Forrest Carter is a Cherokee and works for the Cherokee tribe.

Carter presents the Cherokee people as the most intelligent Native American tribe since they speak English and they have newspapers in two languages, Cherokee and English. In The Outlaw Josey Wales, he also writes "Laura Lee was stunned. The savage spoke English. She looked across at Lone, "You... that is... ye speak our language," she said haltingly, half afraid to address him". (Carter, 2011: 15). He shows that white people wonder how a savage man, a Cherokee, can speak their language, English.

In The Education of Little Tree, Forrest Carter tells the reader of the efforts of the boy's Cherokee grandparents to understand the world outside their world. He writes in a section of this novel entitled Shadows on a Cabin Wall:

"In the evenings of the winter, we sat in front of the stone fireplace. Lighter knots, taken from the centers of rotted stumps, sputtered and flickered from the thick, and resin, throwing on the wall shadows that jumped and contracted, only to leap up again, making the walls come alive with fantastic etchings appearing and disappearing, growing and receding. There were long silences while we watched the flames and dancing shadows. Then Grandpa would break the silence with some of his comments on the "readings"." (1976: $13)$.

The Cherokee people read books in their own way. They know how to get more knowledge. They also make a reading session a very special occasion in their daily life. They make it interesting with some other memorable elements. It is also a kind of discursive meeting since they give comments in the reading. They set a regular schedule for their readings and also spend a lot to hold a reading night. In the novel Carter writes how much they spent with the use of coal oil which is expensive and difficult to get.

"Twice a week, every Saturday and Sunday night, Granma lit the coal oil lamp and read to us. Lighting the lamp was a luxury, and I'm sure it was done on account of me. We had to be careful of the coal oil. Once a month, me and granpa walked to the settlement, and I carried the coal oil can with a root 
stuck in its snout, so that not a drop was spilled on the way back. It cost a nickel to fill it, and granpa showed a loy of trust in me, letting me carry it all the way back to the cabin". (1976: 13)

Carter writes they need books, even canon class books, to read. It is not easy but they try to get the books. They try to explore the world by selecting the best books that they like to read. Forrest Carter in the novel The Education of Little Tree writes:

"When we went, we always carried a list of books made out by Granma, and Granpa presented the list to the librarian, and turned in the books that Granma had sent back. She didn't know the names of modern authors, I don't suppose, because the list had the name of Mr. Shakespeare (anything we hadn't read by him, for she didn't know the titles) '. (1976: 1314)

Carter writes that they like good books written by a good author. It seems Carter likes to say that in the novel, the Cherokee grandparents explore the world of an author that they like.

It is not enough to have the books needed to learn. They then continue their learning with a different activities; learning to make up sentences. You can find it in the novel

"We kept the dictionary checked out all the time, as I had to learn five words a week, starting at the front, which caused me considerable trouble, since I had to try to make up sentences in in my talk through the week using the words. This is hard, when all the words you learn for the week start with $A$, or $B$ if you're into the B's'. (1976: 14).

When reading specific books such as Macbeth and The Decline and Fall of the Roman Empire, Grandpa, a strong character in the novel, gave very special responses. Carter describes the responses as follows:

"When granma read about Macbeth, I could see the castle and the witches taking shape in the shadows, alive in the cabin wall, and I'd edge closer to Granpa's rocker. He'd stop rocking when granma got to the stablings and the blood and all. Granpa said none of it would come about if Lady Macbeth had minded doing what a woman was supposed to do and kept her nose out of the business that rightly ought to have been done by Mr. Macbeth, and besides, she wasn't much of a lady, and he couldn't figure out why she was called such, anyhow. Granpa said all of this in the heat of the first reading. Later on, after he had mulled it over in his mind, he commented that something was undoubtedly wrong with the woman (he refused to call her Lady)". (1976: 15).

Carter highlights the desire to learn and intelligence of Cherokee people to choose what they do in their free time. He, that is told as the boy in the novel, joins the reading session with his granma and granpa. He listens and sees how granpa tries to understand what granma reads. 
Paul Johnson (1997) similarly characterizes the Cherokee people based on historical records:

"John Quincy Adams, who was always hostile to Indians, had to admit that a delegation of Cherokees who came to see President Monroe in 1824 were 'most civilised.' 'These men,' he recorded, 'were dressed entirely according to our manner. Two of them spoke English with good pronunciation and one with grammatical accuracy" (1997: 236).

Paul Johnson is showing that the Cherokee tribe is different from other Native American. They wear clothes and hey speak English well just like educated people.

Paul Johnson also writes how the Cherokee people and a number of other tribes appeared more civilized to the whites of the time than other tribes:

"In fact the Indians varied enormously. the Creeks, Cherokees, Choctaws, Chickasaws, and Seminoles, who bore the brunt of white aggression, had long been known as the 'Five Civilized Tribes'." (1997: 236)

To Johnson, the Apache tribe is not one of the most civilized Native American tribes. It is a general knowledge that public has about this Native American tribe. They are always fighting against the interest of white people in the U.S. They are at war with the U.S. Army to defend their lands. It means they are killing or being killed.

However, Forrest Carter chooses Apache to tell in his Watch for Me on the Mountain. He tells how Geronimo becomes the warrior-leader of the Apache. He starts from telling the childhood of Gokhlayeh. It is a name of a boy that learns the Apache way of life. He must struggle to survive and in his teen years, he starts to know that war is the life of the Apache and becomes an Apache warrior after he is chosen by his people.

In Watch for me on the Mountain, Forrest Carter tells how the Apache warriors fight against the white men in the same way as how Josey Wales does in his The Outlaw Josey Wales who chooses to fight against the Federal Union Army. Carter writes that white men, the blue coats, attack a community of Apache when most of the men have left the place to trade and hunt. The bluecoats kills all the women, children and old men staying in the community. The army burns them. When the Apache men return, they find that all their women, children and old men are dead.

The Apache men, then, decide to fight. The other Apache war leaders choose Gokhlayeh to become their new leader. They only want one thing, revenge. Gokhlayeh starts his war career when he and his men attack Kaskiyeh, a place occupied by bluecoats and Mexicans. The name of Geronimo is firstly screamed there. In the novel, Carter writes, "the War Leader Geronimo was born where Kaskiyeh died" (1978: 122).

After the war in Kaskiyeh, Geronimo rides to attack the white men and Mexicans. When "the chiefs and maintained they must regard other matters 
than war - the safety of families and the securing of the best life possible for the people to whom they were responsible" (1978: 124), Geronimo chooses total war. His argument is rejectedby almost all the chiefs of the Apache, but he chooses his own way.

The story of the Apache tribe and Geronimo in Watch for Me on the Mountain is not only about Native American but also a story of white northerner army represented by bluecoats and Mexican soldiers. The bluecoats and Mexican soldiers kidnap Native American and sell them as slaves. In this case, the Apache is a special tribe. The white northerners' plan, shown in the story is to depopulate this tribe. They kill the Apache men and their children and rape their women. Forrest Carter shows how Geronimo leads the attacks against the white northerner and Mexican soldiers to take revenge.

Megan Kate Nelson (2016) explores this conflict in the context of the Civil War period in her article The Civil War from Apache Pass. She writes "You see the Civil War as not only a fight between white men over the right to own slaves, but also a series of conflicts between American Indians and Anglo Americans over the right to self-determination." For Nelson, the U.S Civil War is not only a war between white men who defend slavery and white men who fight to abolish slavery in the U.S. but also a war between Native American and white men.

Nelson writes that the war between the white men and Native American is the war of American Indians and Anglo Americans. However, Carter does not only portray those two parties in Watch for Me on The Mountain. Carter also writes how the church involves and has a special power.

Carter tells how the church is given a special authority by the army. He describes it in chapter 12 of Watch for Me on The Mountain.

"Father Dominique retired to the coolness of his chambers. He always felt irritation at the conflict of powers between Church and the military. In truth, he had the right to dispense all punishment for crimes, whether civil, military, or Church charged. But in the last few years the gradual incursions of the military into the powers of the Church had opened the way for jealous donkeys like Capitan Felipe to insinuate themselves into positions of power. He resented the incessant quibbling and disscussion that occured as a consequence between himself and the captain, with the whining fat alcalde always presenting himself, as mayor, to represent what he liked to call "civil authority." (1978: 113 -114)

Carter writes that the church used to have a conflict with the army, but the church is subsequently given a power that is called "civil authority". With this authority, Carter writes, "the church has the right to dispense all punishments for crimes, whether civil, military, or Church charged." (1978: 114) which includes punishments for Native American. 
The church thinks that Native American are not people of "reason" so that the church cannot administer The Holy Eucharist to them. For this context, Carter writes,

"He had baptized some, to wash away sin, but they were still lost, kept barely within the bounds of civilized actions by the whipping post and stocks of standing close by the cathedral. There was even doubt and animated debate within the Church hierarchy as to whether the Indios in fact possessed souls. Father Dominique was sure they did not". (1978: 114 -115)

In other words, according to Forrest Carter, at the time Native American including Apache tribe are considered uncivilized people.

In chapter 13, Carter also writes of the need for Native American slaves in the gold mines, including the ones belonging to the Church.

"The mortality rate of the mine-working Indians was appalling; like mercury, they were used quickly and gone. But unlike mercury, the supply was diminishing. Four years was the average life span of an Indian working the mines. Carrying bags of ore weighing up to four hundreds pounds up long ladder poles from varying depth levels for fourteen to sixteen hours a day, some never saw the sun. The Indians' alarming rate of death was overreaching the births." (1978: 143-144)

The mines need Native American to become their slaves, but they have to work too hard. Many Native American slave die. The number of Native American slaves diminishes. The army works with the church to solve this matter. Carter tells that it happens in Nuri.

Nuri is a place where Colonel Gomez leads his Mexican troops. His responsibilities include providing the mines with more Native American slaves, especially when the mortality rate of mine-working Native American is high. He and the priests of the church manage the work of Native American slaves so that they have enough time to reproduce so it means that the mines will have more Native American slaves in the future. Forrest Carter describes the situation as follows:

"The church struggling to keep the mines operational, had launched a long-range plan that was apparently falling. Ordering that no female Indios used in mine labor. The Church had urged a breeding program with an announced birth goal of four children per Indio male, in four years' time. But the Indios failed in this propagational program; births were few. Perhaps, Colonel Gomez had suggested to the priest, the hours were a little too long; perhaps if the workday was shortened to, say, twelve hours ... after all, a man ..." (1978: 144).

The war between the Apache tribe and the white men is also a war of fighting the slavery program of the white men. The conflict arises when the Apache tribe do not want their people to become slaves of the white men. 
Nelson (2016) also writes about similar places and persons to the ones Forrest Carter's novels. We can find Chiricahua Mountains as the site of the war. We also find Cochise and Mangas Coloradas as the Apache leaders. So what we are being told by Forrest Carter in his novels is not solely from his imagination but from real events. In Nelson's history of this period, we can find that Carter is portraying a common opinion about the war between white men and the Apache. What can be seen is Carter fashioning the story for his novel from history.

Nelson describes the threat Geronimo posed to the US Army and writes, "The army committed more resources to the Southwest after 1866, building the larger second Fort Bowie in 1868 and devoting manpower and money to trying to defeat Cochise and Geronimo". Nelson identifies Geronimo as one of the war leaders of the Apache who becomes a target of the white men's army. This situation is almost the same as the one written by Forrest Carter. Carter writes Geronimo is not only a war leader but also a war shaman.

However, there is something more than only showing the Cherokee's smartness and Apache's war skills and heroism. Carter uses Native American to show that he lives peacefully with Native American in their areas. He is not the same as some white northerners who attack Native American and grab their land. The white northerners force Native American to live in areas that is far away from white communities and kill many of them.

Carter's writings have shown us that Native American are important to him. He uses Native American politically in his writings. He successfully shows how Cherokee tribe display their smartness to live in the mountains and adjust to modern life, and how Apache people demonstrate their war skills and heroism. Both are represented in detail in Carter's novels.

Carter has also illustrated that he is not like the white northerners who let some Native American women live because of their economic potential but then they sold the Native American women to other whites. Then, the whites that belong the Native American women make them slaves, and some also rape them.

Moreover, Carter seems like to be known as a Cherokee like what he has written in The Education of Little Tree. Even in the opening page of The Outlaw Josey Wales, readers can find a paragraph to introduce Forrest Carter. It is written as follows

"Forrest Carter, whose Indian name is Little Tree, is known as Storyteller in Council to the Cherokee Nations. Orphaned at the age of five, he lived with his grandpa (half Cherokee) and his grandma (full Cherokee) in Tennessee until their deaths when he was ten. He has been on his own ever since. He has worked ranches in the South and Southwest - calls Dallas County, Texas, home. History is his main interest, especially of the South- 
Southwest and the Indian; he uses the council storytelling method of the Indian in passing on the history of his people. A number of Indian organisations will share in the proceeds of this book".

Carter likes to make people know that he has an Indian name and he is one of Cherokee nation living in the south. He also shares that what he does is supported by some Native American organizations.

Nevertheless, Dana Rubin (1992) writes

"No one in the family ever called Asa Little Tree. According to Eleanor Friede, Carter's wife maintains that the family is of Cherokee Descent. But Doug Carter insists that there isn't any Indian Blood in the family."

What is stated by Carter's brother, Dough Carter, is a clue of thinking that Forrest Carter has a hidden agenda. He writes his novels to have something from public.

It is good to recall what has been stated by Lowndes (2002). Lowndes writes that Forrest Carter lived in an environment of people who defended the supremacy of white southerners. He also had a political ideology aspiring to a society with whites as the highest class of humans. He fought for it and against people who opposed his ideology. Lowndes adds in his article

"He (Forrest Carter) went on to become the leader of the statewide White Citizens' Council and public speaker for the white supremacist American States' Rights Association."

As a matter of fact, a novel can become a medium for attracting people attention. Forrest Carter uses a good chance to make his readers know what he likes to promote. He uses his novels to present white and Native American relations in 1860s. He writes of white domination with the U.S. Army pushing the Cherokee and Apache people from their lands in the interests of white people. For his interests, Carter uses the memory and understanding of his readers about some events in a particular period of time in history to pursue his targets.

In a political perspective, Carter tries to win the public opinion. In his novels, Carter writes some political persuasion. He promotes his political ideas to public with his novels. He tries to influence public with his writings. He makes use his writings about Native American to have sympathy.

Carter's writings are propaganda as defined by Nicolas O'Shaughnessy (2018). He writes

"Propaganda is a version of political persuasion and a term which long predates political marketing since it represents a form of pre-commercial influence - that is to say, it revolves around speeches and auditoria, powerful rhetoric, resonant symbols and compelling mythologies" (2018: 3)

Carter's writings are political persuasion. The words are written as a powerful rhetoric that is intended to persuade people to like his ideology of 
being a southerner who fights for his ideology and fight against people who do not agree with him.

\section{Conclusion}

Novels will be more attractive and meaningful when they are interpreted in a careful way. The interpretation will make readers get more valuable knowledge from them. One theory to interpret novels carefully is historicism. With historicism, readers can present important historical events to make them understand what the author likes to say.

Forrest Carter is a controversial author. He uses some stories of Native American to make readers consider him someone who befriends Native American people. He wants his readers to know that he is not the same whites who subordinate Native American. He promotes that he has a good relation with Native American.

He even likes to be known as an Indian in one of his novels but it is denied by his brother. Dough Carter insists that they are not Cherokees. It is a controversy to give public a clue to think that there is a hidden agenda of Forrest Carter in writing his novels.

With his novels, Carter successfully attracts his readers' attention. He makes them know that the other whites, northerners, attacks Native American in southern areas of U.S. The northerners kill, sell, enslave and rape Native American. He wants his readers know that he does not do all bad things that the white northerners do to Native American.

Carter promotes that he is a white southerner. He wants people to recognize that white southerners are the highest class whites. He insists that white southerners deserve the highest position in southern areas of U.S. He also wants people to know that white southerners accept Native American and they can live together with Native American people.

In a political perspective, Carter uses stories of Native American in his novels to win public opinions. He wants people to know that he is not the same as whites coming from northern part of U.S. He wants public to realize that he is a southerner who dreams a different dream from the one of northerners. He aims to make his writings become political persuasion to persuade people to agree with his ideology of being a southerner. He also intends to show that he fights for his ideology and he fights against people who do not agree.

\section{Acknowledgment}

This article is a part of my research dissertation of The Doctorate program (S3) of Humanities Department - Gadjah Mada University Yogyakarta. My appreciation goes to LPDP (Lembaga Pengelola Dana Pendidikan) of The Indonesian Republic Ministry of Financial for funding this research. My gratitude is also for Prof. Dr. Juliasih S.U and Muh. Arif 
Rokhman P.hD., M. Hum from Gadjah Mada University Yogyakarta for supervising this research.

\section{References:}

1. Ankersmit, Frank. (2012) Meaning, Truth, and Reference in Historical Representation. New York: Cornell University Press.

2. Beiser Federick C. 2011. The German Historicist Tradition. New York: Oxford University Press.

3. Boyer, Paul S. Clifford E. Clark, Jr, Sandra McNair Hawley, Joseph F. Kett, Andrew Rieser, Neal Salisbury, Harvard Sitkoff, Nancy Woloch. 2008. The Enduring Vision: A History of American People. Boston: Wadsworth.

4. Carter, Forrest. 2011. The Outlaw Josey Wales. EPUB File.

5. 1976. The Education of Little Tree. Albuquerque: University of New Mexico.

6. 1978. Watch for Me on the Mountain. New York: Delta.

7. Corbett, P.Scott, Volker Janssen, John M. Lund, Todd Pfannestiel, Paul Vickery, Sylvie Waskiewicz. 2016. US History. Hosuton: Openstax and Rice University.

8. Fixico, Donald L. 2009. "American Indian History and Writing from Home: Constructing an Indian Perspective." American Indian Quarterly 33, no. 4: 553-560. http:/www.j.stor.org/stable/40388487.

9. Hamilton, Paul. 1996. Historicism. New York: Routledge.

10. Johnson. Paul.1997. A History of American People. New York: Harper Collins.

11. Lebow, Richard Ned. 2009. Counterfactuals, History and Fiction. Historical Social Research, Vol. 34. No. (128). GESIS. Leibniz.

12. Lowndes, Joseph E. 2002. "Unstable Antistatism: The Left, the Right, and "The Outlaw Josey Wales". International Journal of Politics, Culture, and Society Vol 16 no. 2. Springer.

13. Nelson, Megan Kate. 2016. "The Civil War from Apache Pass". The Journal of the Civil War Era, Volume 6, Number 4, December 2016, pp.510-535. North Carolina: The University of North Carolina Press.

14. O'Shaughnessy, Nicolas. 2018. Marketing the Third Reich: Persuasion, Packaging and Propaganda. New York: The Routledge.

15. Rubin, Dana. 1992. The Real Education of Little Tree. www.texasmonthly.com. Ret. on 26 January 2019 